\title{
Fremmedlegeme i koronarkar
}

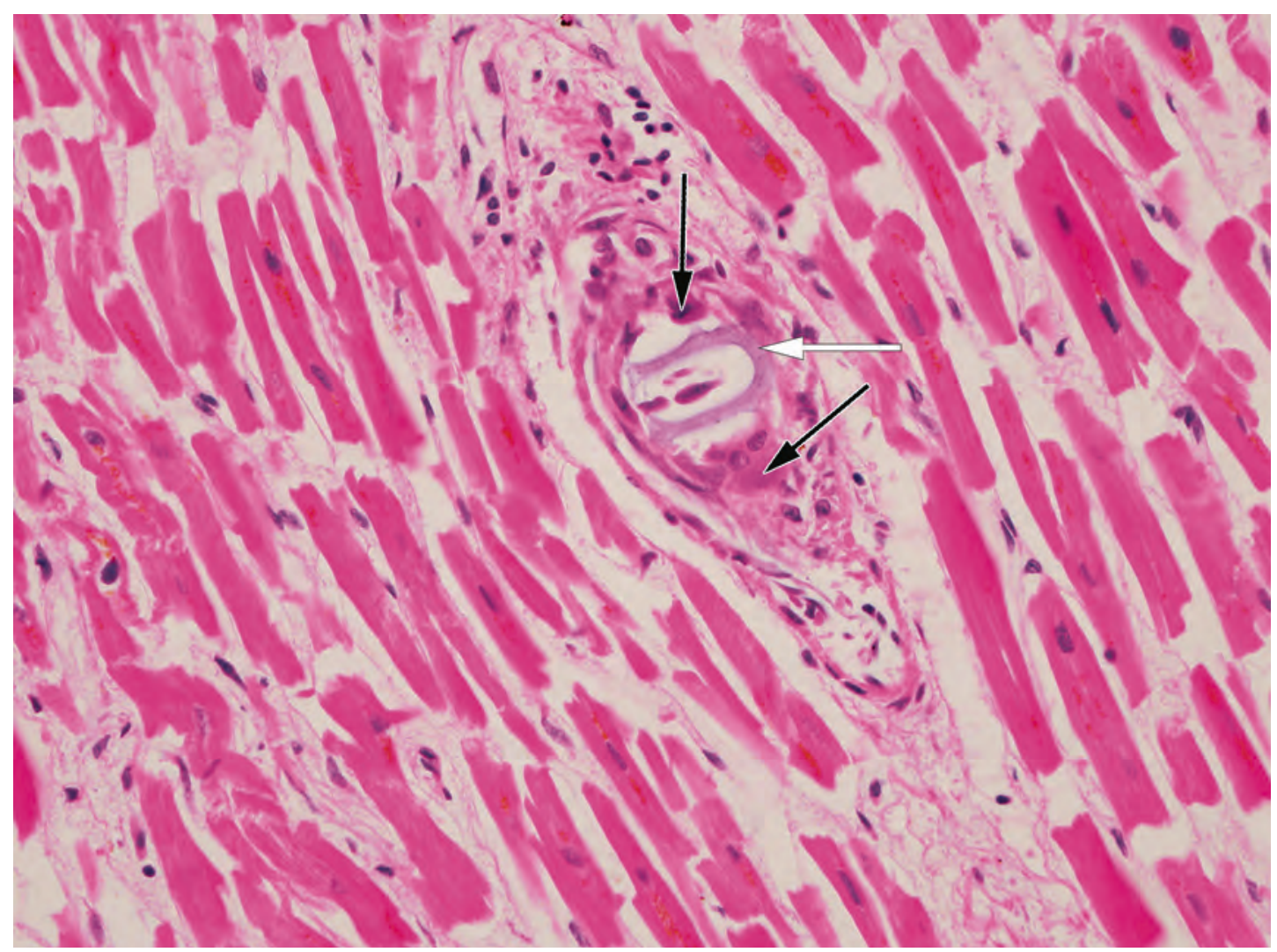

En kvinne i 60-årene gjennomgikk et hjerteinfarkt, og ble behandlet med innsettelse av tre medikamentavgivende stenter i koronarkarene. Inngrepet forløp ukomplisert. Hun døde imidlertid uventet fem dager etter utskrivning. Ved obduksjon ble det funnet en okkluderende trombe i en av stentene og dette ble ansett som sannsynlig dødsårsak.

Ved mikroskopisk undersøkelse av hjertemuskulaturen fant man flere små intramurale arteriegrener okkludert av et basofilt fremmedlegememateriale slik pilen på bildet viser. I de fleste affiserte karene var det flerkjernede kjempeceller rundt materialet (svarte piler). I noen kar var det også en mer utbredt betennelsesreaksjon med lymfocytter og plasmaceller rundt de flerkjernede kjempecellene. Funnet passet med hydrofile polymergelemboluser $(1,2)$.

Polymerbelegg brukes på ulike intravaskulære instrumenter, inkludert katetre og medikamentavgivende stenter, blant annet for å gjøre manipulasjon enklere, og det er antatt å bidra til å redusere komplikasjoner (1). Bruk av polymerbelegg er imidlertid ikke risikofritt, det kan løsne og gi emboluser. Det er beskrevet funn av polymergel- emboluser i flere forskjellige organer $(1,3)$, og det kan føre til alvorlige komplikasjoner som lungeinfarkt, hjerneslag, arytmier og til og med dødsfall (1). Polymergelemboluser i små intramurale arteriegrener i hjertet er en sjelden komplikasjon, men er også beskrevet i litteraturen (4). Selv om stenttrombosen ble ansett som den umiddelbare dødsårsaken hos vår pasient, kan man etter vår oppfatning ikke se bort fra at fremmedlegemeembolusene kan ha hatt betydning.

Pasientens pårørende har gitt samtykke til at artikkelen blir publisert.

Vi takker overlege Helge Scott ved Avdeling for patologi, Oslo universitetssykehus for analysering av prøven, og Tore Bøhmer Halvorsen, pensjonert overlege i patologi ved St. Olavs hospital, for verdifulle kommentarer.

\section{Johannes Hendricus van der Stoep} arjan_van_der_stoep@hotmail.com Eldbjørg Sandstad

Avdeling for patologi

Sykehuset Innlandet, Lillehammer
Johannes Hendricus van der Stoep (f.1982) er lege i spesialisering ved avdeling for patologi.

Eldbjørg Sandstad (f. 1952) er overlege og spesialist i patologi.

\section{Litteratur}

Mehta RI, Mehta RI, Solis OE et al. Hydrophilic polymer emboli: an under-recognized iatrogenic cause of ischemia and infarct. Mod Pathol 2010: 23: $921-30$

2. Mehta RI, Mehta RI, Fishbein MC et al. Intravascu lar polymer material after coil embolization of a giant cerebral aneurysm. Hum Pathol 2009; 40 1803-7.

3. Allan RW, Alnuaimat H, Edwards WD et al. Embolization of hydrophilic catheter coating to the lungs: report of a case mimicking granulomatous vasculitis. Am J Clin Pathol 2009. 132: 794-7.

4. El-Najjar V, Robinson M. Autopsy demonstration of intramyocardial polymer gel emboli associated with a giant-cell reaction following cardiac catheterization: a case report. Cardiovasc Pathol 2012; 21: $59-61$. 